
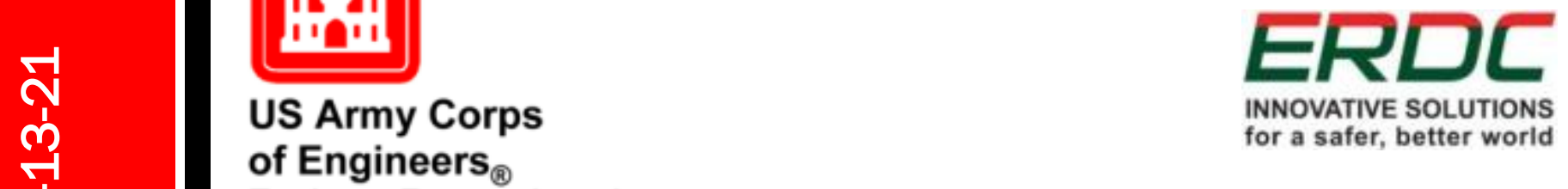

INNOVATIVE SOLUTIONS of Engineers

Engineer Research and

Development Center

\title{
Simulation of Wild Pig Control via Hunting and Contraceptives
}

Jennifer L. Burton, James D. Westervelt, and Stephen Ditchkoff

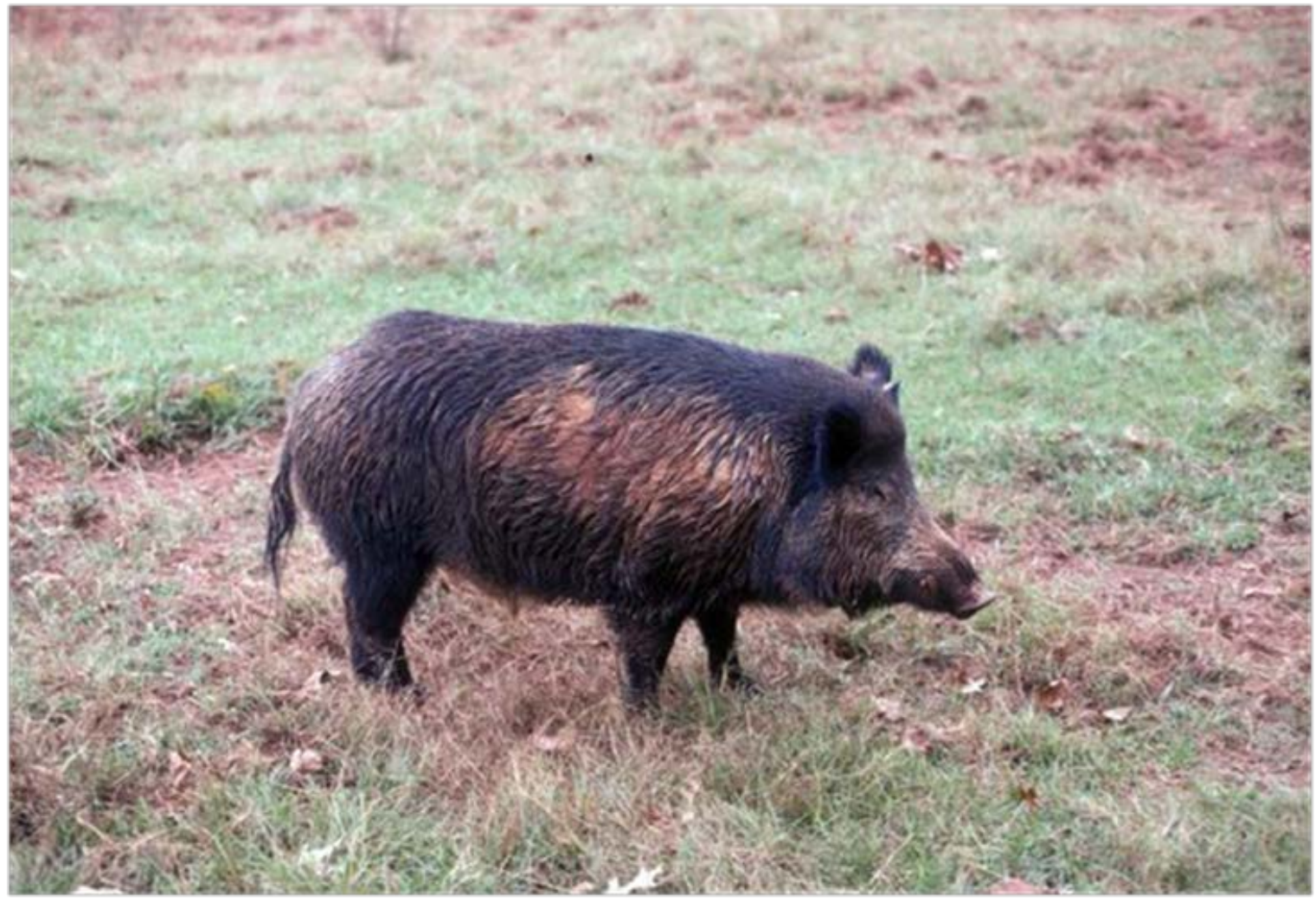


The US Army Engineer Research and Development Center (ERDC) solves the nation's toughest engineering and environmental challenges. ERDC develops innovative solutions in civil and military engineering, geospatial sciences, water resources, and environmental sciences for the Army, the Department of Defense, civilian agencies, and our nation's public good. Find out more at www.erdc.usace.army.mil.

To search for other technical reports published by ERDC, visit the ERDC online library at http://acwc.sdp.sirsi.net/client/default. 


\section{Simulation of Wild Pig Control via Hunting and Contraceptives}

Jennifer L. Burton, James D. Westervelt, and Stephen Ditchkoff

Construction Engineering Research Laboratory (CERL)

US Army Engineer Research and Development Center

2902 Newmark Dr.

Champaign, IL 61822-1076

Final Report

Approved for public release; distribution is unlimited.

Prepared for Headquarters, US Army Corps of Engineers

Washington, DC 20314-1000 


\section{Abstract}

Invasive wild pigs prey on at-risk fauna, disrupt fragile habitat, destroy agricultural crops, and create unique transmission risks for human and livestock diseases such as pseudorabies, swine brucellosis, and avian influenza. Prolific reproduction, generalist feeding behaviors, and adaptive intelligence have impeded eradication efforts, and the inability to predict pig movement diminishes the efficiency and effectiveness of population control techniques. This work developed a spatially explicit individualbased model to compare the impacts of hunting, baiting with oral contraceptives, and the combination of both on the Fort Benning, GA feral pig population. Results suggest that the combination of hunting and contraception would be more effective than either approach used alone. Wildlife managers can use both these results and the model itself to inform management decisions under a variety of conditions at Fort Benning and other sites. Further, this work takes a step toward understanding and predicting feral pig movement drivers, the improved understanding of which could elucidate new options for management of wild pig populations and their impacts.

DISCLAIMER: The contents of this report are not to be used for advertising, publication, or promotional purposes. Citation of trade names does not constitute an official endorsement or approval of the use of such commercial products. All product names and trademarks cited are the property of their respective owners. The findings of this report are not to be construed as an official Department of the Army position unless so designated by other authorized documents. 


\section{Contents}

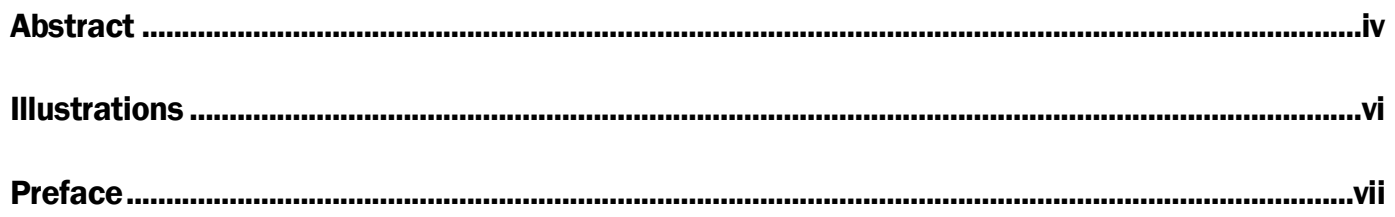

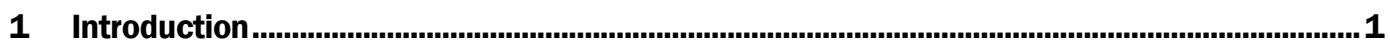

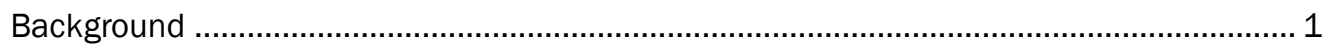

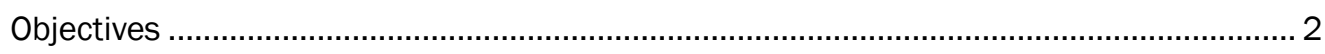

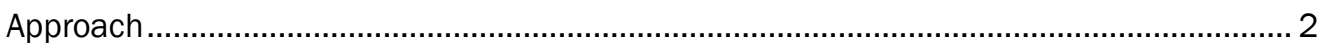

Mode of technology transfer ..................................................................................... 3

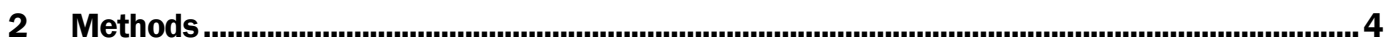

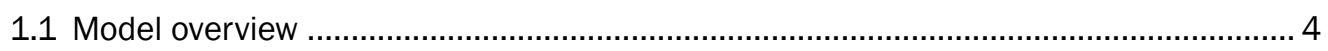

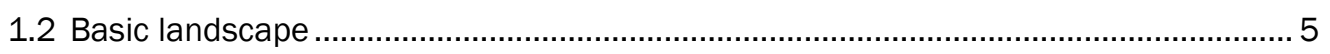

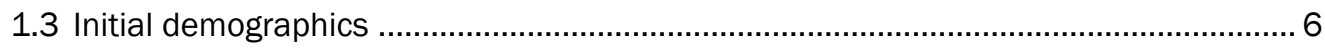

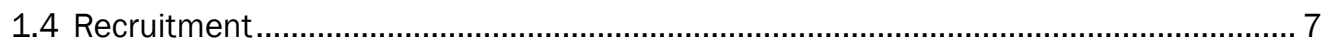

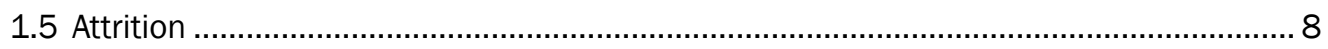

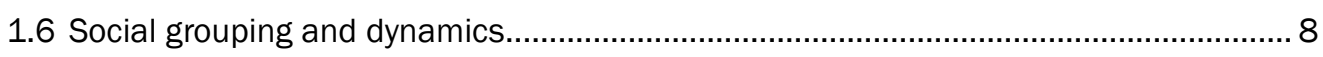

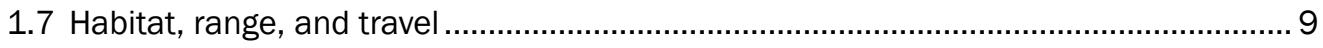

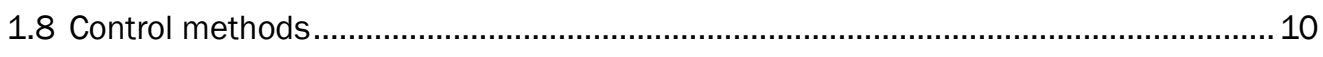

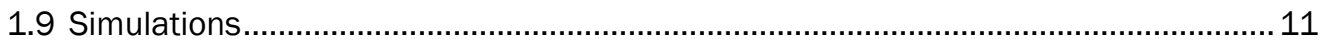

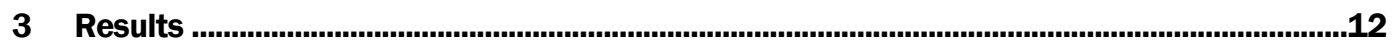

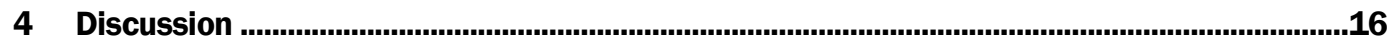

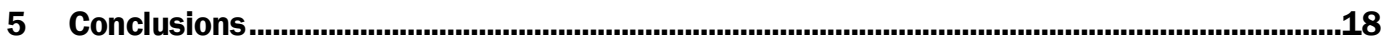

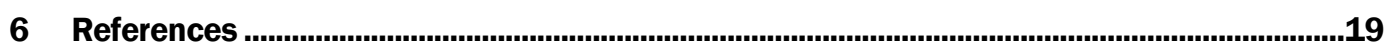

Report Documentation Page (SF 298) ................................................................................22 


\section{Illustrations}

\section{Figures}

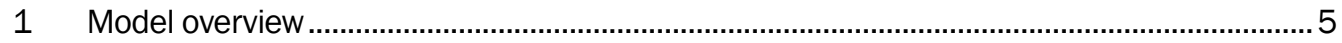

2 Various hunting intensity, no contraceptive bait ................................................................13

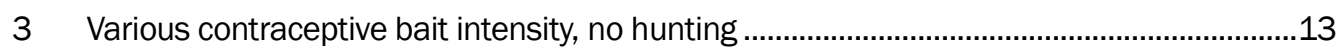

4 Low contraceptive bait intensity, various hunt intensities .....................................................14

5 Low hunt intensity, various contraceptive bait intensities ...................................................14

6 Average population at week 416 for different hunt rates across various bait

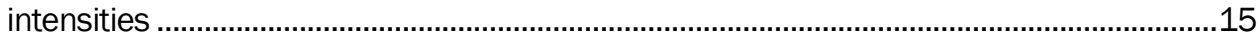

7 Combined moderate hunting and contraceptive baiting intensities ....................................15 


\section{Preface}

This study was conducted for the Office of the Assistant Chief of Staff for Installation Management (OACSIM) under Program "Habit-Centric Species at Risk (SAR) Research to Avoid Future Training Restrictions," Project "Cumulative Multispecies Habitat and Population Viability Analysis." The technical monitor was Dr. Victor Diersing, ACSIM(ISE).

The work was performed by the Environmental Processes Branch (CN-N) of the Facilities Division (CF), Construction Engineering Research Laboratory (CERL). The CERL Principal Investigator was Dr. J ames Westervelt. Appreciation is owed to Marina Drigo, Ying Li, Ariana Peralta, J ohanna Salzer, Kranthi Varala, and J ennifer Burton, who developed the first version of this model as a class project under the direction of Bruce Hannon and J ames Westervelt at the University of Illinois at Urbana-Champaign. This work was vastly improved by the support of David J olley at Auburn University, Dr. William Sparklin at Montana State University, and Mark Thornton at Fort Benning, GA, each of whom lent expertise regarding salient ecosystems, terrain, and swine. Thanks are also owed to Bruce MacAllister, CEERD-CN-N, for providing valuable help with the modeling process, and to Dr. Mark Honeyman, Dr. Peter Lammers, and Dave Stender at Iowa State University for their assistance with model parameters. At the time of publication, William Meyer was Chief, CEERD-CN-N, and Michelle J . Hanson was Chief, CEERD-CF. The Deputy Director of ERDC-CERL was Dr. Kirankumar V. Topudurti and the Director was Dr. Ilker R. Adiguzel.

COL Kevin J. Wilson was the Commander of ERDC, and Dr. J effery P. Holland was the Director. 


\section{Introduction}

\section{Background}

Wild pigs (Sus scrofa), which are an invasive species in North America, are considered to pose a significant threat to ecosystem health across the continent (Ditchkoff and West 2007). As generalist omnivores, they negatively impact many native plant and animal species, both directly via consumption (Tolleson et al. 1993; Hayes et al. 1996; J olley et al. 2010) and indirectly through competition for resources (Gabor and Hellgren 2000). Their proclivity to root for food beneath the soil surface can lead to soil erosion and impaired water quality, increased prevalence of exotic plants, and injury to native plant species (Cushman et al. 2004; Kaller and Kelso 2006; Kaller et al. 2007). They pose a significant health risk to humans and domestic livestock because of their propensity to carry and transmit diseases such as pseudorabies and brucellosis (Wyckoff et al. 2009). Finally, damages to agriculture in the United States each year due to wild pigs has been estimated to be over $\$ 1$ billion (Pimentel 2007).

The serious threat that invasive wild pigs pose in the United States and other countries has led to many efforts at population reduction/ eradication. Most efforts have shown little success; in only a few documented cases have eradication efforts been successful (McCann and Garcelon 2008; Parkes et al. 2010). Most control efforts use lethal control (e.g., trapping and hunting) as the primary means of reducing pig densities. However, their prolific rate of reproduction (Mauget et al. 1991) ensures that feral pigs can quickly replace any individuals that were removed during a lethal control program. Litter sizes are normally from four to six, and females can produce three litters in as little as 14 months (Comer and Mayer 2009). This high rate of reproduction combined with an early age at sexual maturity (5-7 months) (Comer and Mayer 2009) explains why populations quickly recover after a program has ended (Dziecolowski et al. 1992).

Alternative methods of population control will ultimately be required to achieve success in reducing densities of wild pigs. Administration of immune-contraceptives is one such tool that has received attention and that shows considerable promise, despite two apparent drawbacks that raise questions regarding their suitability for reducing densities of wild pigs in field situations: (1) no contraceptives for wild pigs are currently practical 
for use in the field because currently available contraceptive products are either injectable or not species-specific, and (2) contraceptives do not normally sterilize an animal permanently; they must be re-reapplied at some time in the future to maintain their effectiveness.

However, tests with pigs in captivity suggest that contraceptives are very efficient at controlling reproduction (Massei et al. 2008). Since it is likely that a contraceptive practical for field application will be developed, this work was undertaken to model the effects of both lethal eradication (hunting and trapping) and contraception on a population of wild pigs.

\section{Objectives}

The overall objective of this work was to model the effect of contraceptives on a population of wild pigs. Specific objectives were to model and predict: (1) the effectiveness of a contraceptive program at reducing the density of wild pigs on Fort Benning, (2) the effectiveness of a control program incorporating both contraceptives and lethal control, and (3) the manner in which the duration of a contraceptive dose (i.e., how long a pig remains sterile) would influence the success of a contraceptive program.

\section{Approach}

The objectives of this work were accomplished in the following steps:

1. Fort Benning, GA was selected as a location to model feral hog population because this population has received considerable study in recent years (Hanson et al. 2008; Hanson et al. 2009; Sparklin et al. 2009).

2. A spatially explicit model was constructed using a spatially explicit agentbased modeling (ABM) system (NetLogo, Version 4.0.2) of wild pig demographic and spatial characteristics relative to specific features of the Fort Benning, GA landscape.

3. The model was built on a landscape consisting of a $206 \times 213$ grid of cells, with each cell representing a patch measuring 200 x $200 \mathrm{~m}$. All input maps, including hog areas, hunting areas, hard mast production, and access to water, were derived from 2001 National Land Cover Data maps for the area (http://www.epa.gov/mrlc/nlcd-2001.html), and then resampled to this resolution.

4. The model used 1100 individuals created with an initial gender ratio of 1:1 (Hanson 2006). Each individual was randomly assigned an age between the minimum breeding age (31 weeks for males [Sweeney et al. 1979], 26 weeks for females [J ohnson et al. 1982], and 676 weeks [Henry and Conley 
1978]), and was randomly distributed across the landscape in hogaccessible areas. The model was run for 104 1-week time steps (2 years) to generate the population used to start the simulation. The model was used to test all combinations of four hunt scenarios, four contraceptive levels, and five durations of sterility.

5. Results were gathered, conclusions drawn, and recommendations made

\section{Mode of technology transfer}

This report will be made accessible through the World Wide Web (WWW) at URL: http://www.cecer.army.mil 


\section{Methods}

This work modeled the population on Fort Benning, GA (Ditchkoff and Mitchell 2009) because this population has received considerable study in recent years (Hanson et al. 2008; Hanson et al. 2009; Sparklin et al. 2009). Fort Benning is home to several at-risk species of fauna and flora, including the Federally-listed gopher tortoise (Gopherus polyphemus) and relict trillium (Trillium reliquum) that can be negatively impacted by predation and rooting activities of wild pigs. Recent estimates suggest that the number of feral pigs residing on the area is between 2,740 and 7,400 (Hanson et al. 2008), and immigration from adjoining lands supplements this group. A bounty program was instituted on the area from J une 2007 to April 2010 and approximately 3,600 were removed from the area during this period. However, density estimates as recent as 2010 have shown that the population was not reduced (Holtfreter and Ditchkoff, unpublished data). This supports data reported by Hanson et al. (2009) that wild pigs on Fort Benning were able to withstand substantial lethal removal without a decrease in population growth rates. They concluded that both immigration and increased reproductive rates (in response to intensive removal) factor into the ability of this population to withstand lethal control efforts (Hanson 2006). This work hypothesized that population control would be optimized by a combination of lethal removal and contraceptive delivery.

\subsection{Model overview}

A spatially explicit model was constructed using a spatially explicit ABM system (NetLogo, Version 4.0.2) of wild pig demographic and spatial characteristics relative to specific features of the Fort Benning, GA landscape (Figure 1). The model was populated with the best available information about wild pigs in general and the Fort Benning population in particular, but was designed to be readily adaptable to different wild pig populations, control methods, and sites. It covered an area that included all of Fort Benning and Columbus, GA and captured processes that defined landscape characteristics (land cover, land use, vegetation, and water availability), individual hogs, hunting, and contraceptive baits. Behavior of pigs in the dynamic model was represented in reproductive cycles, attrition, social grouping and dynamics, diet and feeding, and movement. 


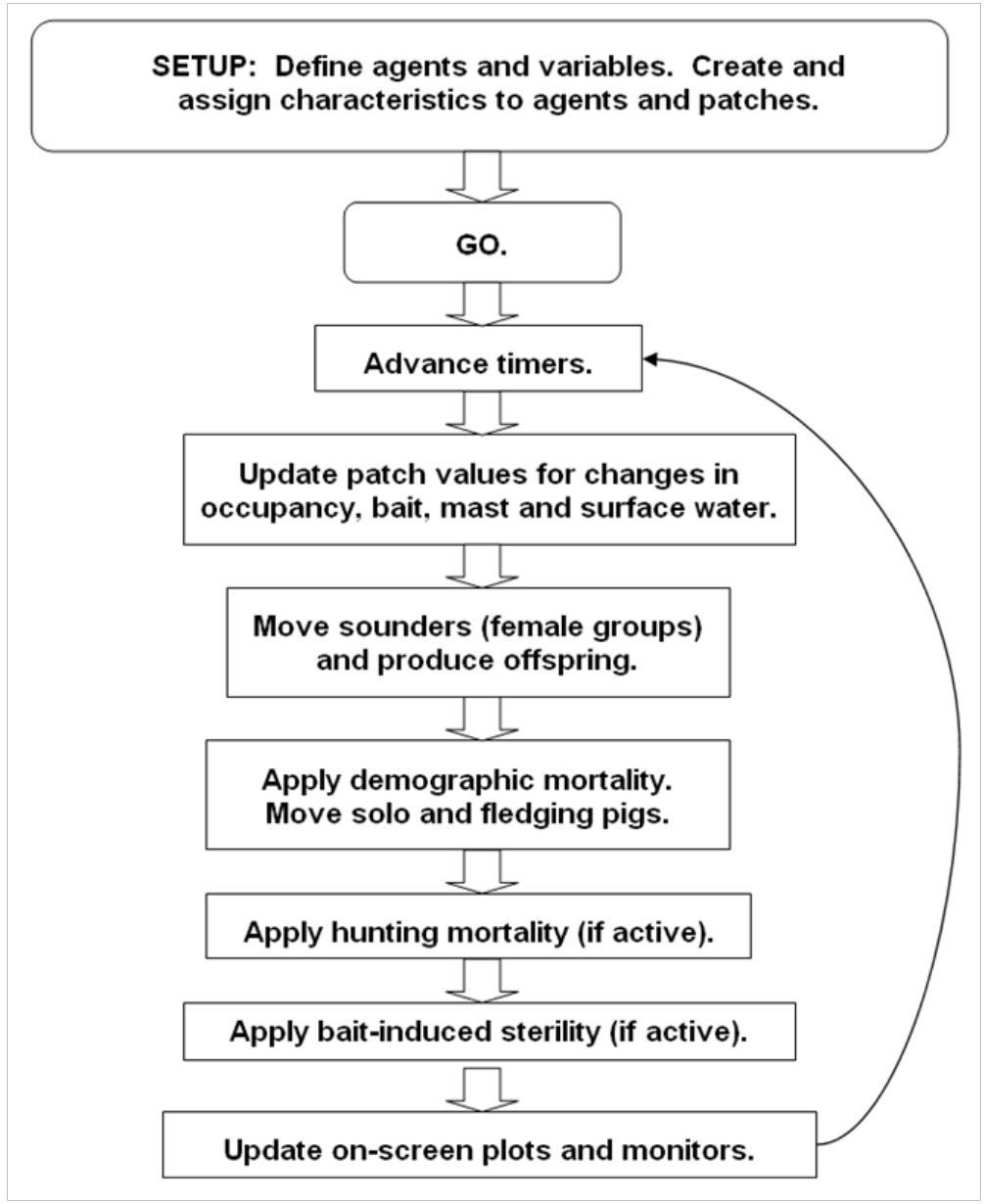

Figure 1. Model overview.

Hog hunting and distribution of contraceptive baits were modeled as individual and combined options for hog control. The equations, parameters, and variables that defined the model were taken from the literature. Data were collected from wild pigs at Fort Benning and from expert advice from Fort Benning environmental staff familiar with that location's wild pig population. The model is described in the following paragraphs with references to useful supporting sources.

\subsection{Basic landscape}

The model was built on a landscape consisting of a 206 x 213 grid of cells, with each cell representing a patch measuring 200 x $200 \mathrm{~m}$. All input maps, including hog areas, hunting areas, hard mast production, and access to water, were derived from 2001 National Land Cover Data maps for the area (http://www.epa.gov/mrlc/nlcd-2001.html), and were then resampled to this resolution. Hogs were allowed access to all areas except for dense urban areas and water bodies; humans were excluded from impact areas only. 
Mast production is generally considered lighter in uplands, and heavier in bottomland woods (Ditchkoff, Auburn University, personal communication). Mast abundance was predicted based on relative local elevation and vegetative cover type. A patch was considered upland if it was in the top half of the elevation range within a 225-patch area. Patches were considered capable of mast production if classified as deciduous forest, mixed forest, woody wetlands, hardwood forest, xeric hardwood, xeric mixed pine-oak, mixed pine and hardwood, or bottomland hardwood. Each lowland patch that was capable of mast production was assigned a mast potential value of 100, while those that were not were assigned a mast potential value of 0 . These assignments were done at a 30-m resolution. The mast value applied to each $200-\mathrm{m}$ patch in the model was the average of mast potential values within a 30-m, 7-patch diameter. At Fort Benning the mast crop begins to fall in September; mast was present in this model from week 39 through to week 13 of the following year, and absent all other times. Although mast availability varies from year to year, it was believed that standardizing mast availability across years would simplify interpretations of model output.

For each patch, the "distance-to-water" was the minimum number of other patches a pig would have to enter to reach surface water. September through February was Fort Benning's wet season, whereas times from March through August were considerably drier. A patch was considered to contain surface water during the dry season (week 8 through 33) if it was classified as open water or if more than 45 ha drained through it. For the wet season, areas containing cypress-gum swamp or freshwater marsh were added to the group of patches presumed to contain water. For both sets of patches, maps were generated that contained the distance from every location to the nearest source of water.

\subsection{Initial demographics}

Population estimates of wild pigs on Fort Benning calculated during earlier studies ranged from 1.15 pigs $/ \mathrm{km}^{2}$ (Holtfreter et al. 2008) to 6.13 pigs/ $\mathrm{km}^{2}$ (Hanson et al. 2008), or 847 and 4,518 total pigs on the installation, respectively. For the simulation, initial demographics were established in a "ramp-up" phase, and 1,100 individuals were created with an initial gender ratio of 1:1 (Hanson 2006). Each individual was randomly assigned an age between the minimum breeding age and 676 weeks [Henry and Conley 1978]), and was randomly distributed across the landscape in hog-accessible areas. Breeding age was defined as 31 weeks for males 
(Sweeney et al. 1979) and 26 weeks for females (J ohnson et al. 1982). The model was run for 104 1-week time steps (2 years) to generate the population used to start the simulation.

\subsection{Recruitment}

Wild pigs normally do not live past 10 years, but can live as long as 14 years (Henry and Conley 1978), and no reproductive senescence has been noted. Female reproductive maturity can occur as early as 21 weeks (J ohnson et al. 1982), and may vary depending on nutrition and exposure to mature boars. While boars may be physiologically capable of breeding around 21 weeks of age, their fertility continues to increase over a period of several months (Flowers 2001). Competition is observed among boars attempting to breed (Pedersen 2007). In this model, gilts (young females) could farrow (give birth) at 43 weeks of age, which correlates to a minimum breeding age of about 26 weeks (J ohnson et al. 1982). Due to the inferior physiological fertility and competitive disadvantage of younger males, boars in this model began breeding at 32 weeks (Sweeney et al. 1979).

While inadequate nutrition (Matschke 1964) and heat stress (Omtvedt et al. 1971; Taylor et al. 1998) have been shown to negatively affect male and female fertility, density-dependent decreases in fertility are generally not observed as long as the population is in good nutritional condition (J olley 2007). Through necropsy of pregnant sows, wild pigs at Fort Benning have been found to carry as few as three to as many as 12 fetuses (J olley 2007). Mean litter size of young females is significantly less than for older females: at Fort Benning, females under 1 year of age produce an average of five piglets, while older sows average 6.87 (J olley 2007; Hanson et al. 2009). In this simulation, females under 1 year of age delivered five piglets, while sows at least 1 year of age had a 13\% likelihood of delivering six piglets and an 87\% likelihood of delivering seven piglets. Hanson et al. (2009) observed a 1:1 gender ratio in the adult pig population at Fort Benning, and in this model, gender was randomly applied to each virtual piglet as it was "born."

Because estrus tends to be synchronized within sow groups, semiannual farrowing schedules were assigned to sounders (sow groups) within the model, as has been described by J olley (2007). Farrowing dates were randomly determined based on a probability distribution that matched previously observed temporal birthing patterns, with peaks occurring in March, and from J uly through November. 


\subsection{Attrition}

For pigs 1 month old or less, conservative survival rates of $42 \%$ were assigned based on limited available data (Barrett 1978; Náhlik 2003). Annual mortality rates (DA) for pigs over 1 month of age were derived directly from Hanson's (2006) apparent survival figures for Fort Benning: females 1-8 months of age ( 0.311$)$, females $>8$ months of age (0.319), males $1-8$ months of age (0.200), males $>8$ months of age (0.207). To correspond with temporal and demographic partitions in the model, these rates were converted to weekly mortality for each age/ gender class using the equation:

$$
\mathrm{DW}=(1-\mathrm{DA}) 1 / 52-1
$$

Equation 1

The resulting figures represent emigration and mortality, including death caused by recreational hunting prior to the implementation of the bounty program. In studies conducted at Fort Benning, very few adult wild pig deaths were reported due to predators, disease, starvation, or other nonanthropogenic causes. Humans are considered the primary predator for the species. When Hanson et al. (2009) measured apparent survival rates on the installation, hunting was believed to cause approximately $90 \%$ of adult swine mortality.

\subsection{Social grouping and dynamics}

Sow groups, or sounders, at Fort Benning typically consist of one to three sows and their piglets, with an average of 2.59 sows (Holtfreter and Ditchkoff, unpublished data). Male piglets typically remain with the sounder until they reach sexual maturity, at which time they may disperse widely, while females remain with the sounder into adulthood (Hirotani 1987). Mature boars generally live and travel alone, but can often be found with intermixed with sounders during the breeding season (Adkins and Harveson 2006). Mature females tend to remain much closer to their original home ranges (Hirotani 1987). Sounders in this simulation contained two or three mature sows and all of their immature offspring. Upon reaching sexual maturity, virtual male offspring left the sounder. When a female reached sexual maturity, she was forced to leave her sounder if it already contained three older females. The expelled females then formed new sounders, with pigs in closer proximity more likely to end up in the same group. Each new sounder convened at the cluster of at least nine unoccupied patches nearest to a randomly selected member. 


\subsection{Habitat, range, and travel}

Although cover can be essential for habitat selection depending on hunting pressure (Hanson and Karstad 1959), wild pigs are observed in a broad range of habitats across North America. At Fort Benning, they have been documented occupying all habitat types, with the exception of urban areas (Sparklin 2009). To accurately reflect the spatial distribution of wild pigs, this model excluded pigs from areas classified as urban or open water by National Land Cover Data.

Sounder home ranges at Fort Benning are about 200 to 380 ha, and do not overlap (Sparklin et al. 2009). Swine at this location are observed to move to wetland or bottomland areas within their ranges during the warmer, drier season and into woodlands in the winter when mast becomes available and water is more abundant (Sparklin 2009).

No published data was found for daily total distance walked or for net daily travel. One study found that the maximum distance between points visited on a given day was, on average, 0.4 miles for sounders and 0.7 miles for boars. These extremes in daily position depended on the availability of food and water (Kavanaugh and Linhart 2000; Twigg et al. 2007). Despite ample data regarding habitat preferences and range, specific daily movements of feral pigs are difficult to predict.

Daily net distance traveled by modeled pigs was generated at random and varied from zero to the above-referenced average distances between extreme positions. This randomly-generated distance was applied to each boar and sounder at each time step, except when the constraints described below prevented a pig or group from moving to any adjacent patch. Ranges were not directly limited in size, shape, or environmental characteristics (exœpt as noted above), but emerged as a result of the rules governing pig movement. The separation of sows from the sounder at farrowing was not modeled.

Direction of travel was determined at each time step via a comparison of the attractiveness of patches adjacent to a boar's or sounder's position. Patch attractiveness was a combination of innate patch attractiveness, and the time since the patch was visited by others of the same gender. Innate attractiveness was based on weighted values for indices representing distance to surface water, mast availability, and a random "attractiveness" factor. Distance-to-water and mast values each composed $30 \%$ of innate attractiveness. The remaining $40 \%$ was a random number generated to account for other factors contributing to pig movement. 
The model tracked which boar and which sounder had last visited each patch, and the time since a patch was last occupied. This "pig sign" allowed pigs to determine whether a patch was part of another pig's range, and faded linearly over 52 weeks. The avoidance function decreased the innate attractiveness yielding a patch attractiveness value that resulted in discouraging sounders and boars from entering patches visited within the last year by a pig of the same gender.

Mirroring the behavior of wild pigs at Fort Benning (Holtfreter, unpublished data), simulated pigs moved seasonally among neighboring habitat types, establishing home ranges that provided surface water during the dry season as well as high-quality wintertime mast. At observed population sizes, boar ranges covered the majority of available land. Studies have found boar home ranges to be about twice the size of sounder ranges; however estimated Fort Benning population density and social groupings preclude this. Because the number of boars is between two and three times the number of sounders, the study area is of inadequate acreage to allow for boar ranges larger than the typical area observed to be occupied by sounders at current densities.

\subsection{Control methods}

All pigs in hunter-accessible areas were eligible to be hunted. Hunt-related mortality was tested at levels of $0,25,50$, and 75 pigs killed per month.

Oral baits deliver contraceptives that prevent female pregnancies for 3, 6 , 9,12 , or 24 months. Techniques used in swine population control field trials could include ground placement by hand or aerial drop from a small aircraft, and bait feeding stations. The distribution of different numbers of baits was tested, both in single spatial blocks and by random dissemination among specified numbers of single patches. When the placement function was active, baits were distributed at user-specified intervals, with a default interval of 4 weeks. Baits remained in place for one time step, and only pigs in baited patches were eligible to ingest it. For every patch, the odds that each female pig would become sterile were:

$\mathrm{b} / 2 \mathrm{p}$

Equation 2

where:

$$
\begin{aligned}
& \mathrm{b}=\text { number of baits in patch } \\
& \mathrm{p}=\text { number of pigs in patch }
\end{aligned}
$$




\subsection{Simulations}

The model was used to test all combinations of four hunt scenarios, four contraceptive levels, and five durations of sterility. The hunt levels were 0 , 25,50 , and 75 kills per month. The bait levels were $0,2500,5000$, and 7500 baits placed per month. Durations of sterility were 3, 6, 9, 12, and 24 months. Each scenario was simulated 10 times, and ended when either 12 model years had passed or the simulated population exceeded 12,000 pigs. In each simulation, this modeled population quickly achieved an age distribution similar to that seen in the literature, with only a small percentage of pigs surviving past 2 years of age. Each scenario started with 1100 swine that generated a population after a 104-week (2-year) "ramp-up" during which there was no hunting or baiting. Population growth rates generally remained within the measured range, consistently approaching the $142 \%$ mean observed at Fort Benning (Hanson 2006). 


\section{Results}

Without the use of contraceptive baits, even high-intensity hunting ultimately had little impact on the size of the simulated wild pig population, though it did slightly reduce the rate of population growth (Figure 2). In these figures, each trace represents a trial for a specific set of input parameters. Traces in all figures are truncated before population estimates meet or exceed 12,000 individuals. When used in the absence of hunting, contraceptive baits were similarly ineffective at low intensity (Figure 3). However, when a larger number of baits were placed each month, contraception showed potential for limiting the size of the feral pig population.

With low-intensity contraceptive use, population growth slowed, but did not stop as the number of pigs killed by hunting was increased (Figure 4). In the inverse scenario, when hunting was kept at lowintensity, growth rates were similarly responsive to increases in contraceptive baiting (Figure 5). Population control was consistently achieved at higher hunting intensities in these lower-intensity contraception scenarios.

For any time step, variation in the simulated pig population across treatments was inversely related to treatment intensity. For scenarios in which treatment intensity was adequate to prevent the simulated pig population from reaching 12,000 individuals, greater differences between treatments were seen at the 8- and 12-year time points. Figure 6 shows how the population at the 8-year mark (416 weeks) varied with kill rate, represented by individual lines showing the average population across replicates, and contraceptive bait intensities.

When moderate to high-intensity hunting was combined with contraceptive baiting, population reduction and control were consistently achieved. Population control was feasible with low, moderate, or high-intensity placement of contraceptive baits, in combination with moderate or high-intensity hunting. Figure 7 shows populations changes using monthly totals of 25 kills with 7500 baits, 50 kills with 5000 baits, and 75 kills with 2500 baits. 


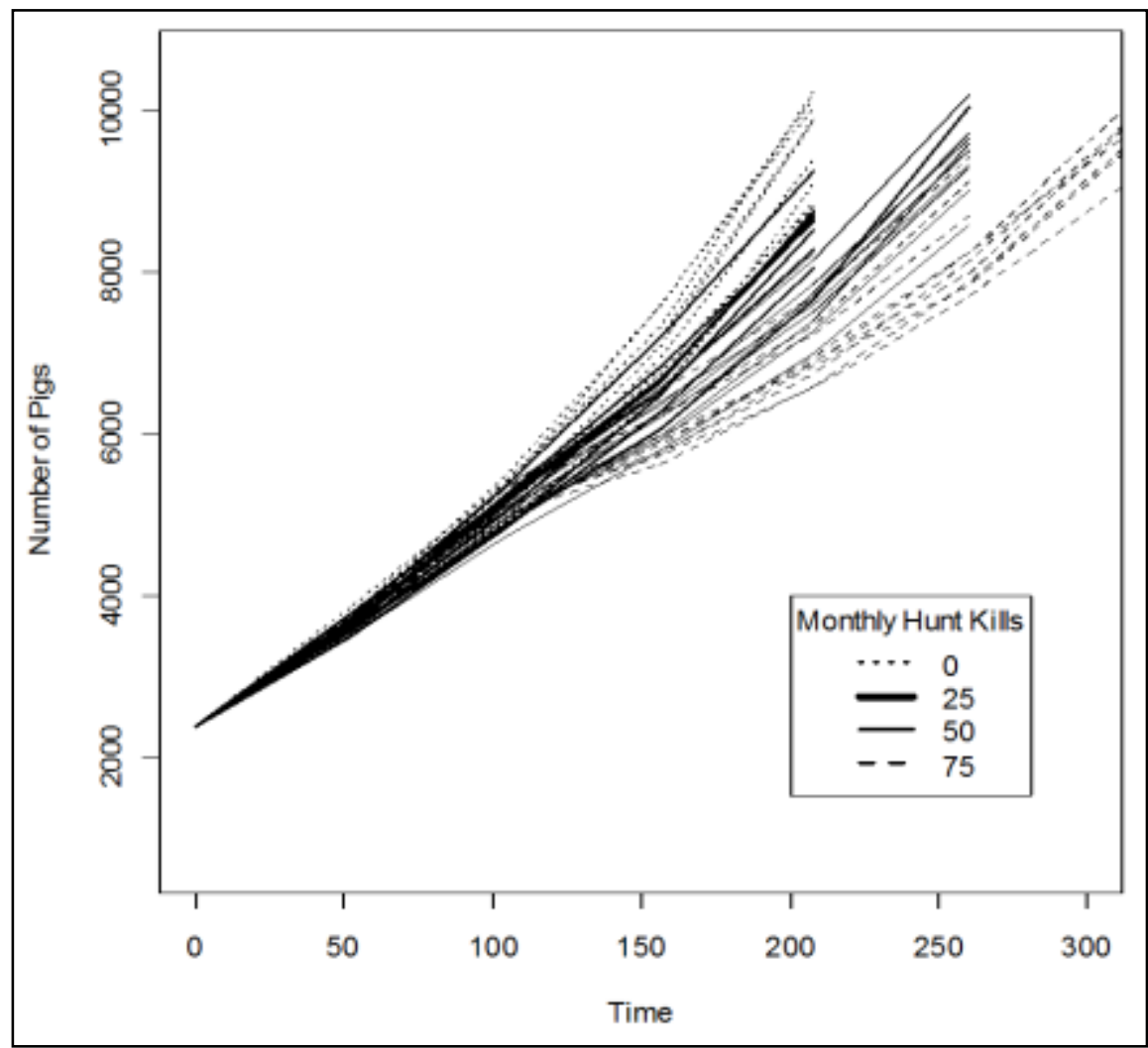

Figure 2. Various hunting intensity, no contraceptive bait.

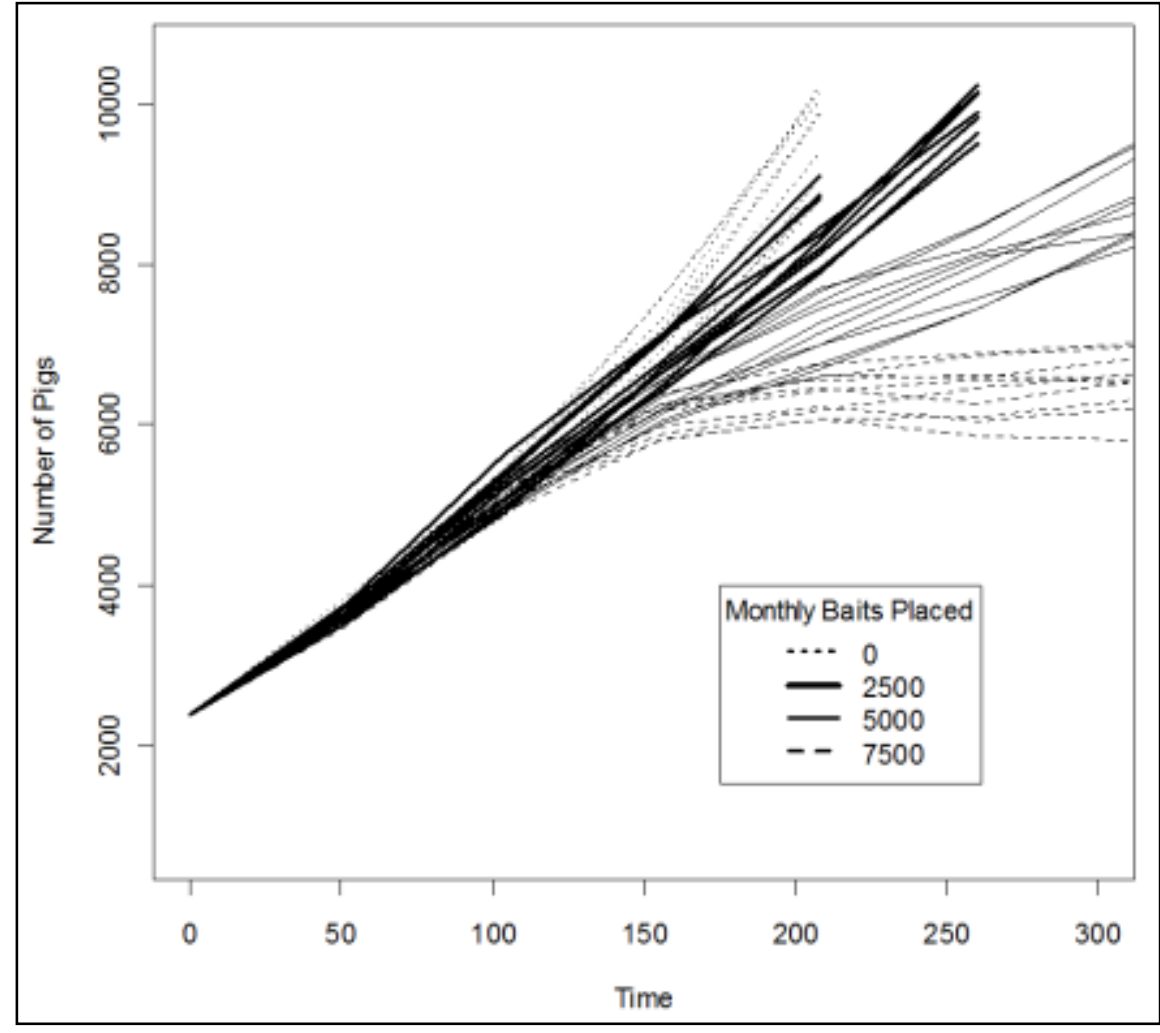

Figure 3. Various contraceptive bait intensity, no hunting. 


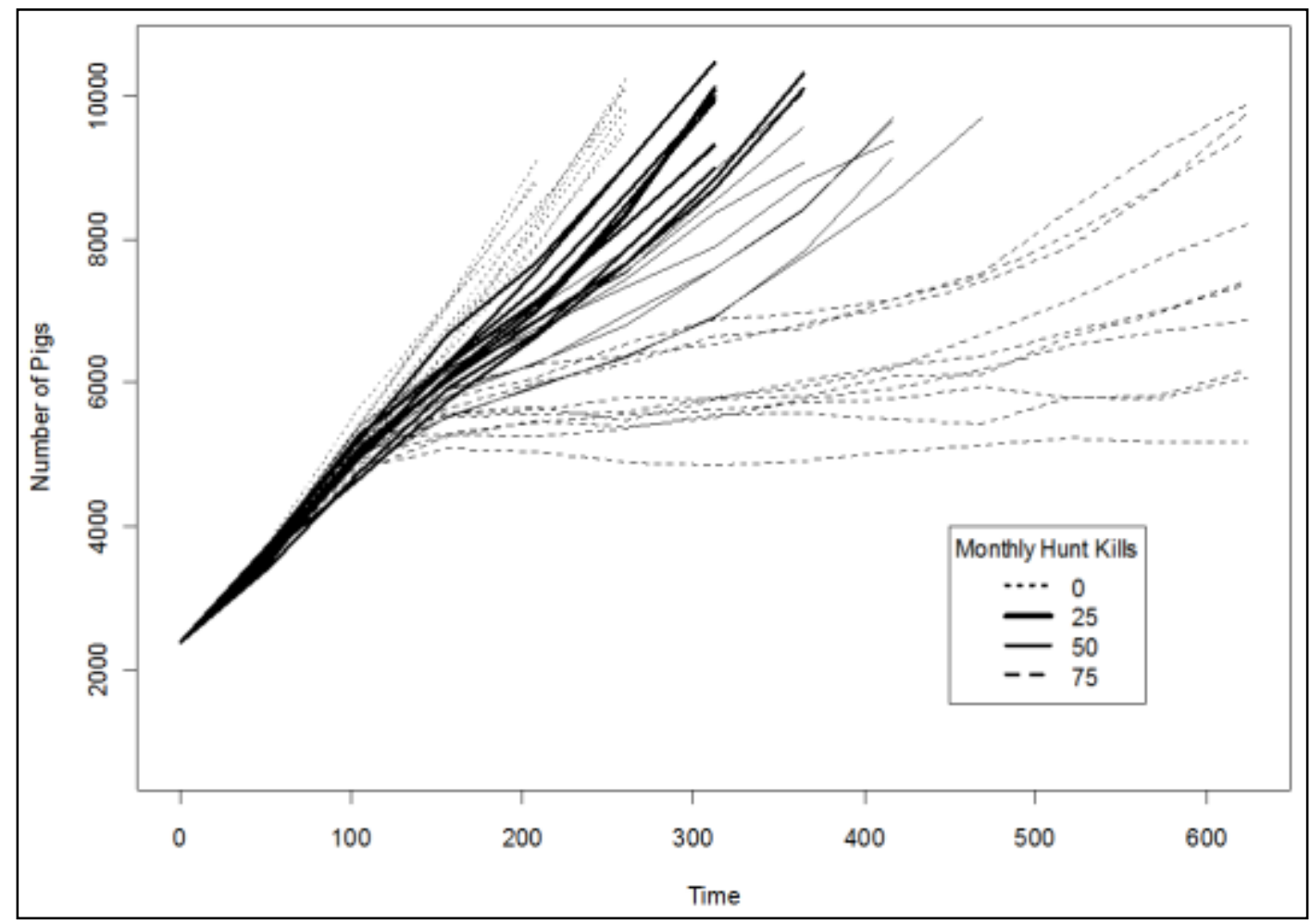

Figure 4. Low contraceptive bait intensity, various hunt intensities.

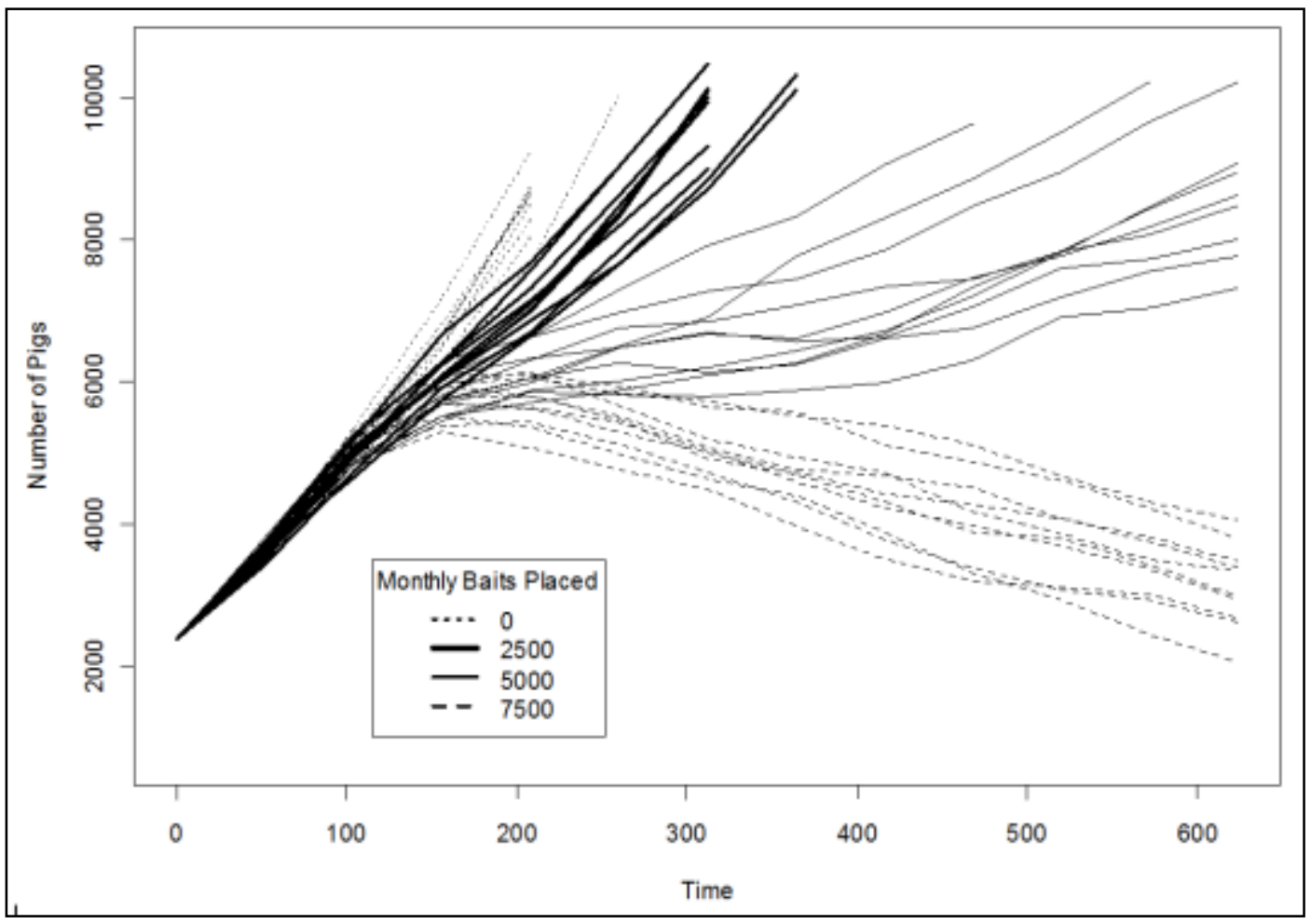

Figure 5. Low hunt intensity, various contraceptive bait intensities. 


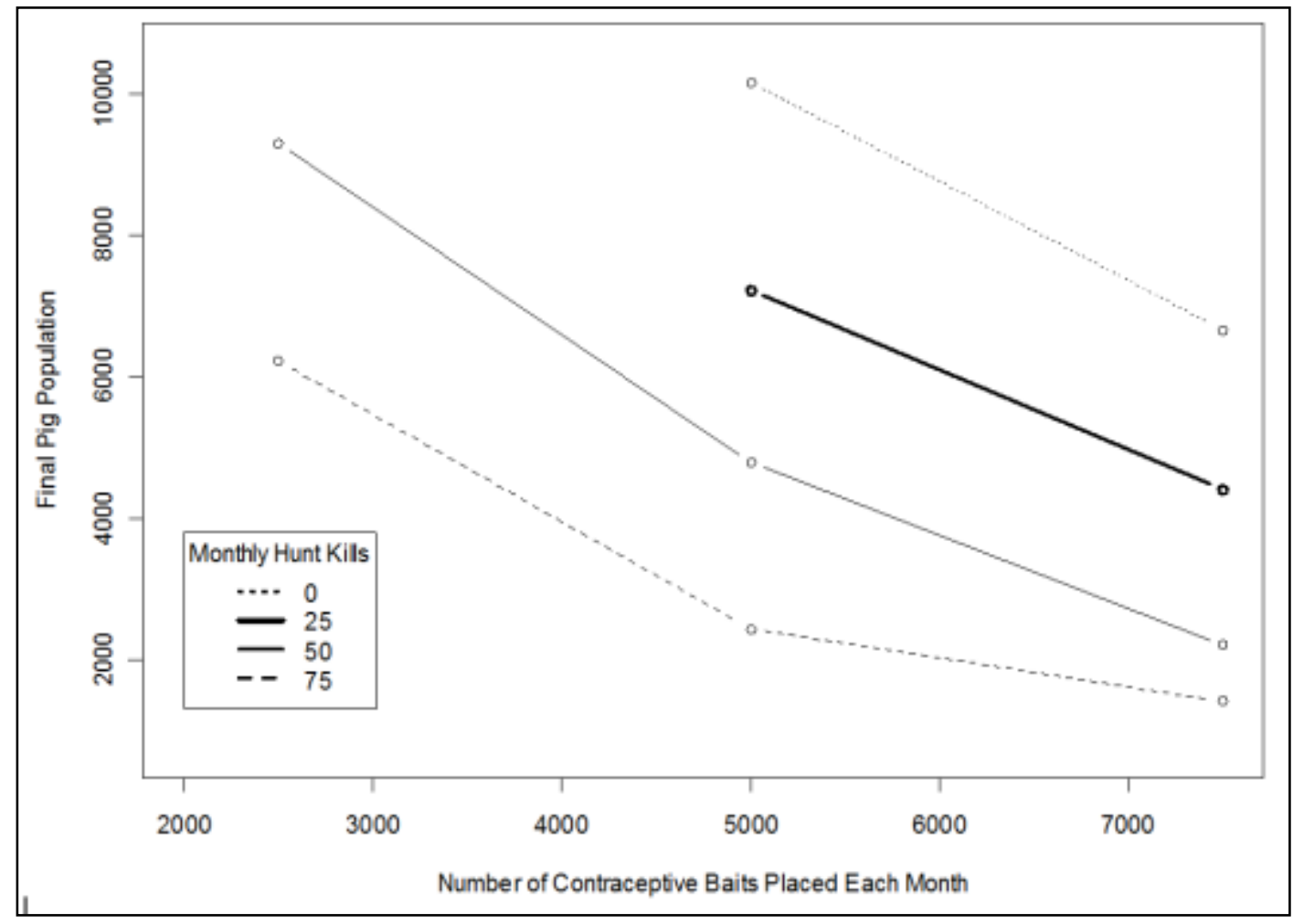

Figure 6. Average population at week $\mathbf{4 1 6}$ for different hunt rates across various bait intensities.

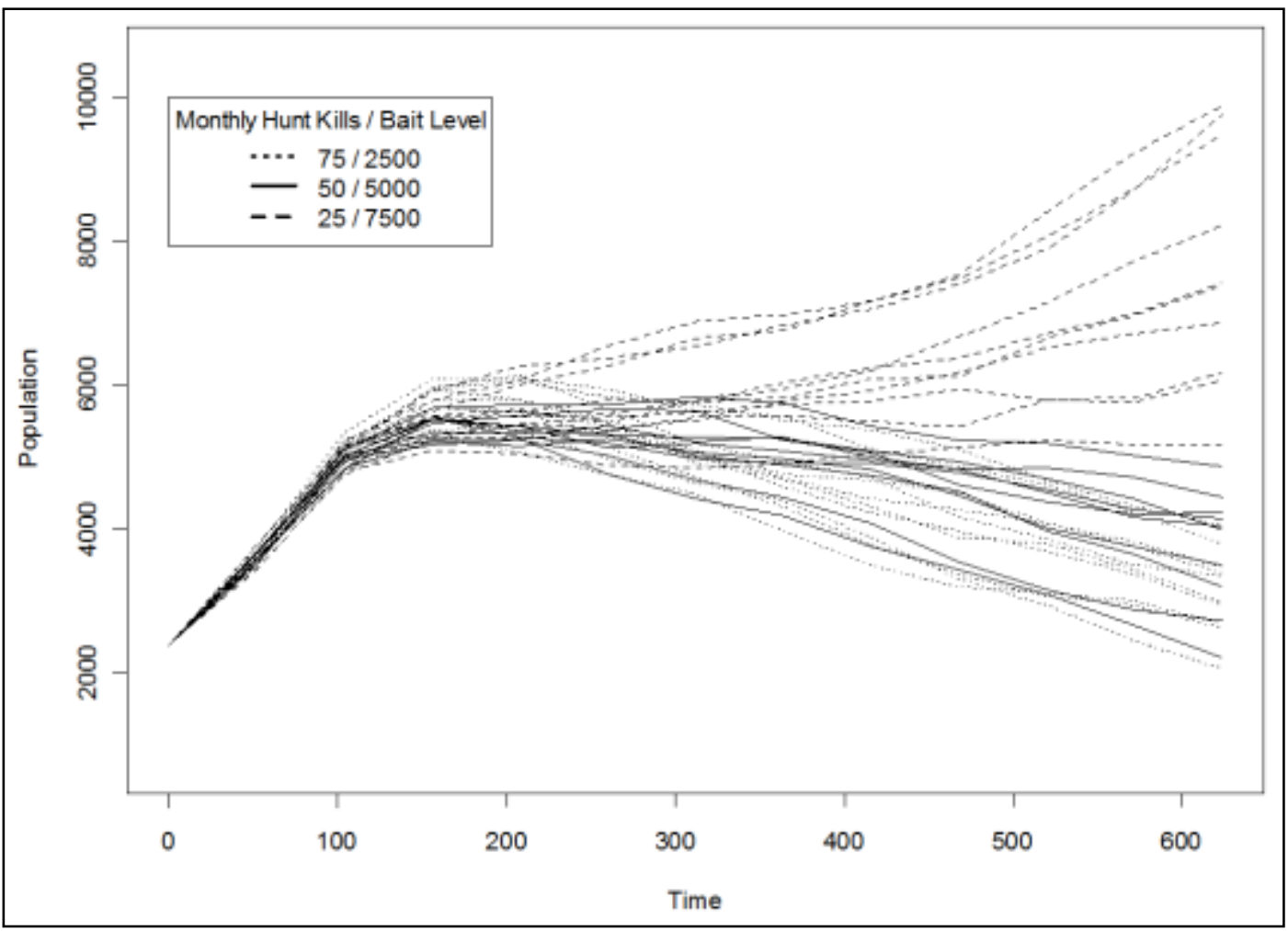

Figure 7. Combined moderate hunting and contraceptive baiting intensities. 


\section{Discussion}

Age distribution, population growth rates, and seasonal movement produced by this were consistent with general data available for wild pigs and with observations specific to the Fort Benning population. Model behavior and results were robust with regard to variation in field data for sounder size and boar ranging behavior. As experienced at Fort Benning, this model predicts that substantial hunting, resulting in 75 pigs killed per month, cannot hold populations below 10,000 individuals. Replacing the hunting program with a contraceptives only program might hold populations below 10,000 individuals with the placement of 5,000 or more baits per month.

The results of this work support the hypothesis that the combination of lethal control and oral contraceptive delivery techniques under development will provide better control of the Fort Benning wild pig population than will either technique alone. In the most successful control scenarios, monthly kill rates for hunting are very high (50 or 75 kills per month) compared to actual rates at Fort Benning, suggesting that a significant increase in hunting could be beneficial. While the actual costs associated with baiting are unknown at this time, the placement of 5,000 or more baits per month can be expected to incur some cost. It is therefore likely that hunting will remain an important part of feral hog population control. An associated unknown is how the actual hunting kill rate might change as hog densities drop in response to more effective population control, however results presented in Figure 2 ( $p$ 13) suggest that lower hunt success rates can be substantially important in an aggressive contraception program.

The impacts of trapping, bait stations, bait-and-euthanize schemes, or the sterilization of males were not evaluated; additional modeling studies are recommended to investigate if and how these techniques might be included in an integrated management program. Behavioral adaptations, such as aversion to hunting and trapping sites or increased frequency of visits to baited areas, have been reported, and could warrant specific attention in the development of long-term control strategies. Variation in surface water availability due to annual climate variation or climate change could also affect pig ranges. It is recommended that future modeling efforts investigate these as potential factors influencing feral pig movement and management. Because a significant decrease in population density could re- 
duce the success rate for both baiting and hunting, future simulations should also investigate results of non-random hunting and baiting locations, such as placement of baits in areas where pigs enter the installation. 


\section{Conclusions}

The results of this study suggest that a combination of lethal and contraceptive techniques is more likely than either method alone to achieve management goals for the Fort Benning wild pig population. Improved control of this population via combined methods is likely to reduce habitat destruction and disease risks to threatened and endangered species, and improve overall achievement of conservation management objectives. In addition, this model provides a framework for understanding how wild pigs interact with the landscape and helps management decision makers predict the effects of proposed control techniques on swine numbers and location. The ability to test such controls could improve cost- and laborefficiency of invasive species management, particularly as control options are re-evaluated in the context of new information, alternative management scenarios, or changing conditions. 


\section{References}

Adkins, R. N., and L. A. Harveson. 2006. Summer diets of feral hogs in the Davis Mountains, Texas. Southwestern Naturalist. 51:578-580.

Barrett, R. H. 1978. The feral hog on the Dye Creek Ranch, California. Hilgardia 46:283355.

Burton, J ., M. Drigo, Y. Li, A. Peralta, J . Salzer, K. Varala, B. Hannon, and J . Westervelt. 2012. A model for evaluating hunting and contraception as feral hog population control methods. Ecologist-Developed Spatially-Explicit Dynamic Landscape Models. Springer-Verlag.

Comer, C. E., and J . J . Mayer 2009. Wild pig reproductive biology. Wild Pigs: Biology, Damage, Control Techniques, and Management. Aiken, SC: Savannah River National Laboratory, pp 51-75.

Cushman, J . H., T. A. Tierney, and J . M. Hinds 2004. Variable effects of feral pig disturbances on native and exotic plants in a California grassland. Ecological Applications. 14:1746-1756.

Ditchkoff, S. S., and M. S. Mitchell 2009. Ft. Benning Military Reservation. Wild Pigs: Biology, Damage, Control Techniques, and Management. Aiken, SC: Savannah River National Laboratory, pp 357-364.

Ditchkoff, S. S., and B. C. West 2007. Ecology and management of feral hogs. HumanWildlife Conflicts. 1:149-151.

Gabor, T. M., and E. C. Hellgren 2000. Variation in peccary populations: Landscape composition or competition by an invader? Ecology. 81:2509-2524.

Graves, H. B. 1984. Behavior and ecology of wild and feral swine (Sus scrofa). J ournal of Animal Science. 58:482-492.

Hanson, L. B. 2006. Demography of feral pig populations at Fort Benning, GA. M.S. Thesis. Auburn, AL: Auburn University, http://www.benning.army.mil/garrison/DPW/EMD/content/PDF/Hanson\%20Thesis.pdf

Hanson, L. B., J . B. Grand, M. S. Mitchell, D. B. J olley, B. D. Sparklin, and S. S. Ditchkoff. 2008. Change-in-ratio density estimator for feral pigs is less biased that closed mark-recapture estimates. Wildlife Research. 35:695-699.

Hanson, L. B., M. S. Mitchell, J . B. Grand, D. B. J olley, B. D. Sparklin, and S. S. Ditchkoff. 2009. Effect of experimental manipulation on survival and recruitment of feral pigs. Wildlife Research. 36:185-191.

Hanson, R. P., and L. Karstad 1959. Feral swine in the southeastern United States. J ournal of Wildlife Management. 23:64-74. 
Hayes, R. B., N. B. Marsh, and G. A. Bishop. 1996. Sea turtle nest depredation by a feral hog: A learned behavior. Proceedings of the Fifteenth Annual Symposium on Sea Turtle Biology and Conservation. NOAA Technical Memorandum MNFSSEFSC 387. Hilton Head Island, SC, pp 129-134.

Henry, V. G., and R. H. Conley. 1978. Survival and mortality in European wild hogs. Proceedings of the Annual Conference of the Southeastern Association of Fish and Wildlife Agencies. 32:93-99.

Holtfreter, R. W., B. L. Williams, S. S. Ditchkoff, and J . B. Grand. 2008. Feral pig detectability with game cameras. Proceedings of the Annual Conference of the Southeastern Association of Fish and Wildlife Agencies. 62:17-21.

Johnson, K. G., R. W. Duncan, and M. R. Pelton. 1982. Reproductive biology of European wild hogs in the Great Smoky Mountains National Park. Proceedings of the Annual Conference of the Southeastern Association of Fish and Wildlife Agencies. 36:552-564.

Jolley, D. B., S. S. Ditchkoff, B. D. Sparklin, L. B. Hanson, M. S. Mitchell, and J . B. Grand. 2010. Estimate of herpetofauna depredation by a population of wild pigs. J ournal of Mammalogy. 91:519-524.

Kaller, M. D., J . D. Hudson, III, E. C. Achberger, and W. M. Kelso. 2007. Feral hog research in western Louisiana: Expanding populations and unforeseen consequences. Human-Wildlife Conflicts. 1:168-177.

Kaller, M. D., and W. E. Kelso. 2006. Swine activity alters invertebrate and microbial communities in a coastal plain watershed. American Midland Naturalist. 156:163-177.

Kavanaugh, D. M., and S. B. Linhart. 2000. A modified bait for oral delivery of biological agents to raccoons and feral swine. J ournal of Wildlife Diseases. 36:86-91.

Massei, G., D. P. Cowan, J . Coats, F. Gladwell, J . E. Lane, and L. A. Miller. 2008. Effect of the GnRH vaccine GonaCon on the fertility, physiology and behaviour of wild boar. Wildlife Research. 35:540-547.

Matschke, G. H. 1964. The influence of oak mast on European wild hog reproduction. Proceedings Annual Conference Southeast Association of Game and Fish Commission. Vol. 18.

Mauget, R., R. H. Barrett, and F. Spitz 1991. Reproductive biology of the wild Suidae. Biology of Suidae, pp 49-64.

McCann, B. E., and D. K. Garcelon. 2008. Eradication of wild pigs from Pinnacles National Monument. J ournal of Wildlife Management. 72:1287-1295.

Náhlik, A., and G. Sándor. 2003. Birth rate and offspring survival in a free-ranging wild boar Sus scrofa population. Wildlife Biology 9 (Supplement 1), pp 37-42.

Omtvedt, I. T., R. E. Nelson, R. L. Edwards, D. F. Stephens, and E. J . Turman. 1971. Influence of heat stress during early, mid and late pregnancy of gilts. J ournal of Animal Science. 32:312-317. 
Parkes, J. P., D. S. L. Ramsey, N. Macdonald, K. Walker, S. McKnight, B. S. Cohen, and S. A. Morrison. 2010. Rapid eradication of feral pigs (Sus scrofa) from Santa Cruz Island, California. Biological Conservation. 143:634-641.

Pedersen, L. J . 2007. Sexual behaviour in female pigs. Hormones and Behavior. 52:6469.

Pimentel, D. 2007. Environmental and economic costs of vertebrate species invasions into the United States. Managing Vertebrate Invasive Species: Proceedings of an International Symposium. Fort Collins, CO: USDA/APHIS Wildlife Services, pp 2-8.

Sparklin, B. D., M. S. Mitchell, L. B. Hanson, D. B. J olley, and S. S. Ditchkoff. 2009. Territoriality of feral pigs in a highly persecuted population on Fort Benning, GA. J ournal of Wildlife Management. 73:497-502.

Sparklin, W. D. 2009. Territoriality and habitat selection of feral pigs on Fort Benning, GA, USA. University of Montana, p 58.

Sweeney, J . M., J . R. Sweeney, and E. E. Provost 1979. Reproductive biology of a feral hog population. J ournal of Wildlife Management. 43:555-559.

Taylor, R. B. 1991. The feral hog in Texas. Federal Aid Report Series Number 28. Austin, TX: Texas Parks and Wildlife.

Taylor, R. B., E. C. Hellgren, T. M. Gabor, and L. M. Ilse. 1998. Reproduction of feral pigs in southern Texas. J ournal of Mammalogy. 79:1325-1331.

Tolleson, D., D. Rollins, W. Pinchak, M. Ivy, and A. Hierman. 1993. Impact of feral hogs on ground-nesting gamebirds. Feral Swine: A Compendium for Resource Managers. Kerrville, TX: Texas Agricultural Extension Service, pp 76-83.

Twigg, L. E., T. Lowe, and G. Martin. 2007. Bait consumption by, and 1080-based control of, feral pigs in the Mediterranean climatic region of south-western Australia. Wildlife Research. 34:125-139.

Wyckoff, A. C., S. E. Henke, T. A. Campbell, D. G. Hewitt, and K. C. VerCauteren. 2009. Feral swine contact with domestic swine: A serologic survey and assessment of potential for disease transmission. J ournal of Wildlife Diseases. 45:422-429. 


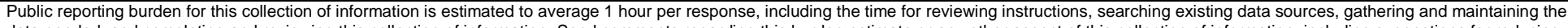

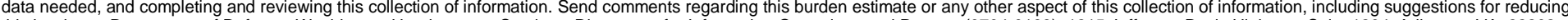

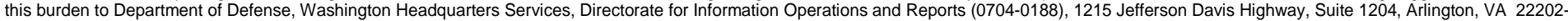

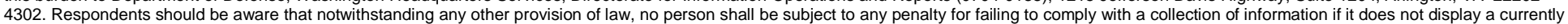
valid OMB control number. PLEASE DO NOT RETURN YOUR FORM TO THE ABOVE ADDRESS.

\begin{tabular}{l|l} 
valid OMB control number. PLEASE DO NOT RETURN YOUR FORM TO THE ABOVE ADDRESS. \\
\hline 1. REPORT DATE (DD-MM-YYYY) 2. REPOR
\end{tabular}

\begin{tabular}{|c|c|}
$15-10-2013$ & Final \\
\hline
\end{tabular}

\section{TITLE AND SUBTITLE}

Simulation of Wild Pig Control via Hunting and Contraceptives

Final

\section{AUTHOR(S)}

J ennifer L. Burton , James D. Westervelt, and Stephen Ditchkoff

3. DATES COVERED (From - To)

5a. CONTRACT NUMBER

5b. GRANT NUMBER

5c. PROGRAM ELEMENT

5d. PROJECT NUMBER

5e. TASK NUMBER

5f. WORK UNIT NUMBER

8. PERFORMING ORGANIZATION REPORT NUMBER

ERDC/ CERL TR-13-21

Construction Engineering Research Laboratory (CERL)

PO Box 9005,

Champaign, IL 61826-9005

\section{SPONSORING I MONITORING AGENCY NAME(S) AND ADDRESS(ES)}

Assistant Chief of Staff for Installation Management (ACSIM)

Presidential Towers

2511J efferson Davis Highway

Arlington, VA 22202

\section{DISTRIBUTION I AVAILABILITY STATEME}

A

Approved for public release; distribution is unlimited.

13. SUPPLEMENTARY NOTES

Report Documentation Page (SF 298)

\section{ABSTRACT}

Invasive wild pigs prey on at-risk fauna, disrupt fragile habitat, destroy agricultural crops, and create unique transmission risks for human and livestock diseases such as pseudorabies, swine brucellosis, and avian influenza. Prolific reproduction, generalist feeding behaviors, and adaptive intelligence have impeded eradication efforts, and the inability to predict pig movement diminishes the efficiency and effectiveness of population control techniques. This work developed a spatially explicit individual-based model to compare the impacts of hunting, baiting with oral contraceptives, and the combination of both on the Fort Benning, GA feral pig population. Results suggest that the combination of hunting and contraception would be more effective than either approach used alone. Wildlife managers can use both these results and the model itself to inform management decisions under a variety of conditions at Fort Benning and other sites. Further, this work takes a step toward understanding and predicting feral pig movement drivers, the improved understanding of which could elucidate new options for management of wild pig populations and their impacts.

\section{SUBJECT TERMS}

Fort Benning, GA, IBM, immunocontraceptives, lethal control, Sus scrofa, hunting, trapping, wild pigs, feral hogs

\section{SECURITY CLASSIFICATION OF:}

\section{a. REPORT}

Unclassified

\section{b. ABSTRACT}

Unclassified c. THIS PAGE

Unclassified

\section{LIMITATION} OF ABSTRACT

SAR
18. NUMBER OF PAGES

30 19a. NAME OF RESPONSIBLE PERSON

19b. TELEPHONE NUMBER (include area code) 